\title{
Molecular and biological characterization of Chilli leaf curl virus and associated Tomato leaf curl betasatellite infecting tobacco in Oman
}

\author{
Muhammad Shafiq Shahid ${ }^{1 * \dagger}$ (D), Muhammad Shafiq ${ }^{1 \dagger}$, Amir Raza $^{1}$, Abdullah M. Al-Sadi $^{1}$ and Rob W. Briddon ${ }^{2}$ (D)
}

\begin{abstract}
Background: In Oman tobacco (Nicotiana tabacum; family Solanaceae) is a minor crop, which is produced only for local consumption. In 2015, tobacco plants exhibiting severe downward leaf curling, leaf thickening, vein swelling, yellowing and stunting were identified in fields of tobacco in Suhar Al-Batina region, Oman. These symptoms are suggestive of begomovirus (genus Begomovirus, family Geminiviridae) infection.

Methods: Circular DNA molecules were amplified from total DNA extracted from tobacco plants by rolling circle amplification (RCA). Viral genomes were cloned from RCA products by restriction digestion and betasatellites were cloned by PCR amplification from RCA product, using universal primers. The sequences of full-length clones were obtained by Sanger sequencing and primer walking. Constructs for the infectivity of virus and betasatellite were produced and introduced into plants by Agrobacterium-mediated inoculation.

Results: The full-length sequences of 3 begomovirus and 3 betasatellite clones, isolated from 3 plants, were obtained. Analysis of the full-length sequences determined showed the virus to be a variant of Chilli leaf curl virus (ChiLCV) and the betasatellite to be a variant of Tomato leaf curl betasatellite (ToLCB). Both the virus and the betasatellite isolated from tobacco show the greatest levels of sequence identity to isolates of ChiLCV and ToLCB identified in other hosts in Oman. Additionally clones of ChiLCV and ToLCB were shown, by Agrobacterium-mediated inoculation, to be infectious to 3 Nicotiana species, including N. tabacum. In N. benthamiana the betasatellite was shown to change the upward leaf rolling symptoms to a severe downward leaf curl, as is typical for many monopartite begomoviruses with betasatellites.

Conclusions: The leaf curl disease of tobacco in Oman was shown to be caused by ChiLCV and ToLCB. This is the first identification of ChiLCV with ToLCB infecting tobacco. The study shows that, despite the low diversity of begomoviruses and betasatellites in Oman, the extant viruses/betasatellites are able to fill the niches that present themselves.
\end{abstract}

Keywords: Geminivirus, Begomovirus, Betasatellite, Chilli leaf curl virus, Tomato leaf curl betasatellite, Nicotiana tabacum

\footnotetext{
* Correspondence: mshahid@squ.edu.om

${ }^{\dagger}$ Muhammad Shafiq Shahid and Muhammad Shafiq contributed equally to this work.

${ }^{1}$ Department of Crop Sciences, College of Agricultural and Marine Sciences,

Sultan Qaboos University, Al-Khod, 123 Muscat, Oman

Full list of author information is available at the end of the article
}

(c) The Author(s). 2019 Open Access This article is distributed under the terms of the Creative Commons Attribution 4.0 International License (http://creativecommons.org/licenses/by/4.0/), which permits unrestricted use, distribution, and reproduction in any medium, provided you give appropriate credit to the original author(s) and the source, provide a link to the Creative Commons license, and indicate if changes were made. The Creative Commons Public Domain Dedication waiver (http://creativecommons.org/publicdomain/zero/1.0/) applies to the data made available in this article, unless otherwise stated. 


\section{Background}

Viruses of the genus Begomovirus (family Geminiviridae) cause economically important diseases of many crops throughout tropical and subtropical regions. Begomoviruses have circular single-stranded (ss) DNA genomes, that are encapsidated in distinctive twinned icosahedral (geminate) particles and are transmitted exclusively by the whitefly Bemisia tabaci [1]. The genomes of begomoviruses are either bipartite, consisting of two $\sim 2.6-2.8 \mathrm{~kb}$ genomic components known as DNA A and DNA B, or monopartite, consisting of a single $\sim 2.6-2.8 \mathrm{~kb}$ component that is a homolog of the DNA A of bipartite viruses. The majority of begomoviruses native to the New World are bipartite, whereas the majority of begomoviruses native to the Old World (OW) are monopartite [1]. The genomes (or DNA A components) of begomoviruses originating from the OW encode six genes. In the complementary-sense the genes encode the replicationassociated protein, the transcriptional-activator protein, the replication-enhancer protein and the (A) $\mathrm{C} 4$ protein. The two genes in the virion-sense encode the (A) V2 protein and the coat protein [2].

Most monopartite begomoviruses are associated with a group of ssDNA satellites collectively known as betasatellites [3, 4]. Betasatellites are approximately half the size of their helper begomoviruses $(\sim 1.4 \mathrm{~kb})$ and depend on the helper virus for their replication, movement in plants and transmission between plants [4]. The structure of betasatellites is highly conserved comprising of a sequence rich in adenine (A-rich), a sequence conserved between all betasatellites, known as the satellite conserved region (SCR), that contains a predicted hairpin structure with the nonanucleotide sequence TAATATTAC forming part of the loop, and a single conserved (between all betasatellites) gene with a capacity to encode an $\geq 118$ amino acid product known as $\beta C 1$ [5].

The first disease caused by a begomovirus in Oman was identified in 1993, although the causative viruses and satellites were not characterized until much later [6]. Despite this the identified diversity of begomoviruses and betasatellites in Oman remains low relative to the known diversity on the Indian sub-continent. The majority of these viruses and satellites appear to have been introduced to the country or have evolved from introduced species. In this respect Oman holds an unusual position, being at the front of a meeting of begomoviruses introduced from Africa, such as Tomato leaf curl Sudan virus and African cassava mosaic Zanzibar virus $[7,8]$, begomoviruses and satellites introduced from the Indian sub-continent, such as Chilli leaf curl virus (ChiLCV) and Tomato leaf curl betasatellite (ToLCB [9]; ), and viruses native to the Middle East region, such as Tomato yellow leaf curl virus (TYLCV) and Watermelon chlorotic stunt virus $[10,11]$.
The study described here has analysed the etiology of a leaf curl disease of tobacco recently identified for the first time in Oman. The results show that the disease is associated with ChiLCV and ToLCB. Additionally Agrobacterium-mediated inoculation of the cloned virus and betasatellite were used to satisfy Koch's postulates. The significance of the findings is discussed.

\section{Methods}

DNA extraction and initial detection of a begomovirus and satellite by polymerase chain reaction

Total nucleic acid was extracted from leaf samples using a cetyltrimethylammonium bromide-based method [12] and kept at $-20^{\circ} \mathrm{C}$. Extracted DNA was used as a template in polymerase chain reaction (PCR) with primer pairs for the detection of begomoviruses (TYLCD-356 (5'-ATCATT TCCACKCCCGYCTCGA-3' /TYLCD-1044 5' -GCRTGM GTACABGCCATATACA-3'), amplifying an $~ 800 \mathrm{nt}$ product, betasatellites (Sat101/Sat102), amplifying an $1350 \mathrm{nt}$ product [13], and alphasatellites (DNA101/ DNA102), amplifying an 1380 nt product [14]. Additionally the primer pair $\beta C 1 F$ (5'-AGACCCGGGATGAC GATCAGATATAATAACA-3')/ßC1R (5'-ACGTCGAC TCACACACACACTTTCGTACA-3'), amplifying a $350 \mathrm{nt}$ product, was used in PCR for the detection of betasatellites.

\section{Rolling circle amplification, cloning and sequencing}

Circular DNA molecules in nucleic acid samples were enriched using rolling circle amplification (RCA) as described earlier [15]. Restriction of the high molecular weight concatameric RCA products with BamHI resulted in $\sim 2.7 \mathrm{~kb}$ fragments, which were eluted from agarose gels using a GeneJet Gel Extraction Kit (Thermo Fisher Scientific) and cloned in BamHI restricted pGEM-3zf $(+)$ (Promega Madison, USA). Potentially full-length clones resulting from RCA (for begomovirus) and PCR (for betasatellite) were sequenced commercially using the primerwalking approach (Macrogen Inc., South Korea).

\section{Sequence assembly and analysis}

Sequences were assembled using SeqMan, part of the Lasergene package of sequence analysis software (DNA Star Inc., Madison, WI, USA). Related sequences available in the GenBank database were identified using the Basic Local Alignment Search Tool nucleotide (BLASTn) [16] run on-line (http://blast.ncbi.nlm.nih.gov/Blast.cgi). Open reading frames $(\mathrm{ORFs})$ in sequences were identified using the ORF Finder program run on-line (https://www.ncbi. nlm.nih.gov/orffinder/). The Species Demarcation Tool (SDT), with the MUSCLE option, was used to calculate sequence identity values [17]. Pairwise multiple sequence alignments were produced using the MUSCLE algorithm implemented in MEGA6 [18]. The evolutionary 
relationships between sequences were determined by constructing phylogenetic trees using Clustal X (neighborjoining method) and displayed using Treeview [19].

\section{Production of constructs for Agrobacterium-mediated inoculation of plants}

Clone Tob11was digested with HindIII and SalI to release a fragment of $\sim 1000 \mathrm{bp}$ which was ligated into the binary vector pGreen0029 [20]. Then the full-length insert of Tob11, released using HindIII, was ligated into the pGreen0029 clone containing the fragment, linearized using HindIII, to yield a partial direct repeat of the virus genome. A similar strategy was used to produce a construct for clone Tob44 in pGreen0029 using a $~ 425$ bp KpnI-XbaI fragment and the full-length insert released using KpnI.

\section{Agrobacterium-mediated inoculation of plants}

Binary vector constructs were electroporated into Agrobacterium tumefaciens strain LBA4404. Agrobacterium inocula were prepared and inoculated to Nicotiana benthamiana, $N$. glutinosa and $N$. tabacum seedlings by agroinfiltration as described previously [21]. Infiltrated plants were maintained in an insect-free growth room at $28{ }^{\circ} \mathrm{C}$ with a photoperiod of $16 \mathrm{~h}$ and monitored daily for the appearance of symptoms.

\section{Southern blot hybridization}

Total genomic DNA $(\sim 10 \mu \mathrm{g})$ extracted from plant tissue was resolved on 1.5\% agarose gels, transferred overnight by capillary action onto Hybond $\mathrm{N}^{+}$membrane (Amersham) and UV cross-linked. Probes were produced by PCR using a DIG-high prime kit (Roche Applied Science) and primers $\beta \mathrm{C} 1 \mathrm{~F}\left(5^{\prime}\right.$-AGACCC GGGATGACGATCAGATATAATAACA-3')/ $\beta$ C1R (A CGTCGACTCACACACACACTTTCGTACA-3') for betasatellite and (qPCRChV F (5'-AGTTCATATAGG GAAGGTTATGTGTA-3') / qPCRChV R (5'- GGAC AAGGAAGAACATCACACTATTC-3') for virus. Membranes were hybridized and washed as described previously [22, 23] and hybridization was detected by colorimetric detection with nitro blue tetrazolium chloride and 5-bromo-4-chloro-3-indolyl-phosphate, toluidine-salt (Roche Applied Science).

\section{Results}

Identification and characterization of a begomovirus and betasatellite infecting tobacco in Oman

During a survey for virus-infected plants in December 2015 on an organic farm in Sohar (Al Batinah region, Sultanate of Oman), fields of tobacco (Nicotiana tabacum) were observed with plants showing severe downward leaf curling, leaf thickening, vein swelling, mild yellowing and stunting (Fig. 1). In the fields between 60 and $70 \%$ of plants were exhibiting symptoms.

Leaves from four symptomatic $N$. tabacum plants, originating from two independent but neighbouring fields $(500 \mathrm{~m}$ apart), were collected, as well as a nonsymptomatic plant from each field. A high molecular weight product was obtained by RCA with DNA extracted from all four symptomatic plants but not from the non-symptomatic plants (results not shown). Three potentially full-length clones (Tob11, Tob12 and Tob13), resulting from digestion of RCA product with BamHI, were obtained, one from each of three N. tabacum plants (Table 1). The sequence of each clone was 2761 nucleotide (nt) in length and are available in the nucleotide sequence databases under the accession numbers given in Table 1. Analysis of sequences showed them to have an organization of genes typical of the genomes of monopartite begomoviruses originating from the OW, with two predicted genes in the virion-sense and four in the complementary-sense (Table 1). SDT analysis showed the three sequences to have greater than 99\% nucleotide sequence identity, showing them to be isolates of a single begomovirus species, based on current guidelines for species demarcation [24]. Comparison of the sequences to sequences available in the GenBank database using BLASTn showed them to have high levels of identity to isolates of the monopartite ChiLCV. Pairwise sequence analysis using SDT, and selected sequences from the database, showed the isolates from tobacco have the highest levels of sequence identity (99.9 to $100 \%$ ) to an isolate of ChiLCV recently identified in watermelon in Oman (KX787939 [25];). This was supported by a phylogenetic analysis based upon an alignment of the full-length sequences of ChiLCV obtained from tobacco and selected sequences from the databases (Fig. 2a). Isolates of ChiLCV originating from

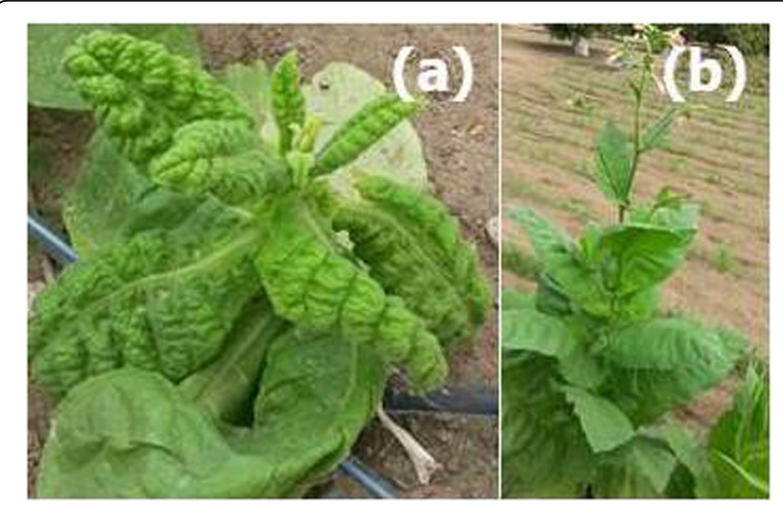

Fig. 1 Tobacco plant exhibiting severe downward leaf curling, leaf thickening, vein swelling, yellowing and stunting symptoms (a) compared to a non-symptomatic tobacco plant (b) growing in the same field 
Table 1 Percentage identity of Chilli leaf curl virus and Tomato leaf curl betasatellite isolated from tobacco to selected other begomoviruses and betasatellites

\begin{tabular}{|c|c|c|c|c|c|c|c|c|c|}
\hline \multicolumn{5}{|c|}{ ChiLCV (Tob11) } & \multicolumn{5}{|c|}{ ToLCB (Tob44) } \\
\hline Accession & $\begin{array}{l}\text { Virus } \\
\text { Acronym }^{a}\end{array}$ & Host species & Country & $\begin{array}{l}\text { Percentage } \\
\text { identity }\end{array}$ & Accession & $\begin{array}{l}\text { Betasatellite } \\
\text { Acronym }^{a}\end{array}$ & Host species & Country & $\begin{array}{l}\text { Percentage } \\
\text { identity }\end{array}$ \\
\hline KX787939 & ChiLCV & $\begin{array}{l}\text { Citrullus } \\
\text { lanatus }\end{array}$ & Oman & 100 & KT180307 & ToLCB & Cucumber & $\begin{array}{l}\text { Saudi } \\
\text { Arabia }\end{array}$ & 95.6 \\
\hline JQ654463 & ChiLCBV & $\begin{array}{l}\text { Amaranthus } \\
\text { viridis }\end{array}$ & India & 81.1 & KT355022 & ToLCB & Corchorus & $\begin{array}{l}\text { Saudi } \\
\text { Arabia }\end{array}$ & 96.3 \\
\hline JQ765395 & ToLCJV & Gaillardia spp. & India & 77.4 & MG571547 & ToLCB & Mentha & $\begin{array}{l}\text { Saudi } \\
\text { Arabia }\end{array}$ & 95.8 \\
\hline KX671562 & PeLCV & Glycine max & Pakistan & 76 & KJ397536 & ToLCB & Papaya & Iran & 94.2 \\
\hline LM645009 & HoLCV & Okra & Pakistan & 76.6 & KF515611 & ToLCKaB & Tomato & India & 85.2 \\
\hline AM491589 & PepLCV & $\begin{array}{l}\text { Capsicum } \\
\text { annuum }\end{array}$ & Pakistan & 75.8 & AM712312 & CLCuMB & $\begin{array}{l}\text { Gossypium } \\
\text { anomalum }\end{array}$ & Pakistan & 81.9 \\
\hline AM691745 & PepLCBV & $\begin{array}{l}\text { Capsicum } \\
\text { annum }\end{array}$ & Pakistan & 75.4 & AY438558 & ToLCRaB & Tomato & Bangladesh & 81.0 \\
\hline KF260965 & TOLCBV & Tomato & Oman & 74.8 & HQ180395 & ToLCBDB & $\begin{array}{l}\text { Nicotiana } \\
\text { tabacum }\end{array}$ & India & 81.0 \\
\hline FJ956700 & TYLCV & Tomato & Oman & 70.5 & AY244706 & PaLCuB & Papaya & India & 69.0 \\
\hline JN591385 & ToLCSDV & Tomato & Oman & 63.6 & AM410551 & CroYVMB & Croton & Pakistan & 65.9 \\
\hline HE862273 & CLCuGeV & Tomato & Oman & 65.3 & KF267444 & OLCuB & Okra & Oman & 28.3 \\
\hline
\end{tabular}

${ }^{a}$ The virus acronyms are given as BYVV Bhendi yellow vein virus, ChiLCV Chilli leaf curl virus, CLCuGeV Cotton leaf curl Gezira virus, HoLCV Hollyhock leaf curl virus, PeLCV Pedilanthus leaf curl virus, PepLCBV Pepper leaf curl Bangladesh virus, ToLCJV Tomato leaf curl Joydebpur virus, ToLCSDV Tomato leaf curl Sudan virus and $T Y L C V$ Tomato yellow leaf curl virus. The betasatellite acronyms are given as CLCUMuB Cotton leaf curl Multan betasatellite, CroYVMB Croton yellow vein mosaic betasatellite, OLCUB Okra leaf curl betasatellite, PaLCUB Papaya leaf curl betasatellite, ToLCBDB Tomato leaf curl Bangladesh betasatellite, ToLCB Tomato leaf curl betasatellite, ToLCKaB Tomato leaf curl Karnataka betasatellite and ToLCRaB Tomato leaf curl Ranchi betasatellite

Oman form a clade distinct from the ChiLCV isolates originating from the Indian sub-continent, with the sequences from tobacco being most closely related to the ChiLCV isolate from watermelon.

Three clones were obtained by PCR with betasatellite primers $\beta 101 / 102$, one each from the three plants from which the virus clones were obtained (Additional file 1: Table S1). The sequences are 1375 (clone Tob45) and 1377 nt (clones Tob44 and Tob46) in length and are available in the nucleotide sequence databases under the accession numbers given in Additional file 1: Table S1. Analysis of the sequences showed them to have an organization and features typical of betasatellites [5], consisting a single conserved (between all betasatellites) ORF in the complementary-sense (known as $\beta \mathrm{C} 1$ ) having the capacity to encode a product of 118 amino acid, a region of sequence rich in adenine (coordinates 722-968 nt) and a sequence well conserved between all betasatellites (known as the satellite conserved region; coordinates $1252-21 \mathrm{nt}$ ) that contains a predicted stem-loop structure with, as part of the loop, the nonanucleotide sequence TAATATTAC with similarity to the origin of replication of geminiviruses.

SDT analysis showed the three betasatellites isolated from tobacco to have between 99.7 and $99.8 \%$ nucleotide sequence identity with each other. Comparison of the three sequences from tobacco to sequences available in the GenBank database using BLASTn showed them to have high levels of nucleotide sequence identity to isolates of the betasatellite ToLCB. Pairwise sequence analysis using SDT, and selected ToLCB sequences from the databases, showed the isolates from tobacco have the highest levels of sequence identity (99.9\%) to an isolate of ToLCB recently identified in watermelon in Oman (KX787940 [25];). Overall the sequences of ToLCB from tobacco showed higher levels of sequence identity to isolates of ToLCB originating from the Arabian Peninsula than to isolates either from Iran or the sub-continent. This is supported by a phylogenetic analysis (Fig. 2b) which shows ToLCB isolates from the Arabian Peninsula, including those identified here in tobacco, form a clade separate from other ToLCB isolates but to be most closely related to isolates from Iran.

\section{Infectivity of cloned ChiLCV and ToLCB}

To satisfy Koch's postulates a partial direct repeat construct of ChiLCV was inoculated to Nicotiana benthamiana, N. glutinosa and N. tabacum plants, either in the presence of absence of a construct for the associated ToLCB (Table 2; Fig. 3). Inoculation of just the ChiLCV construct to $N$. benthamiana seedlings resulted in severe upward leaf curling and vein swelling on the undersides of young, newly developing leaves initiating at 16 days post-inoculation. Co-inoculation of $N$. benthamiana seedlings with the constructs for both ChiLCV and 


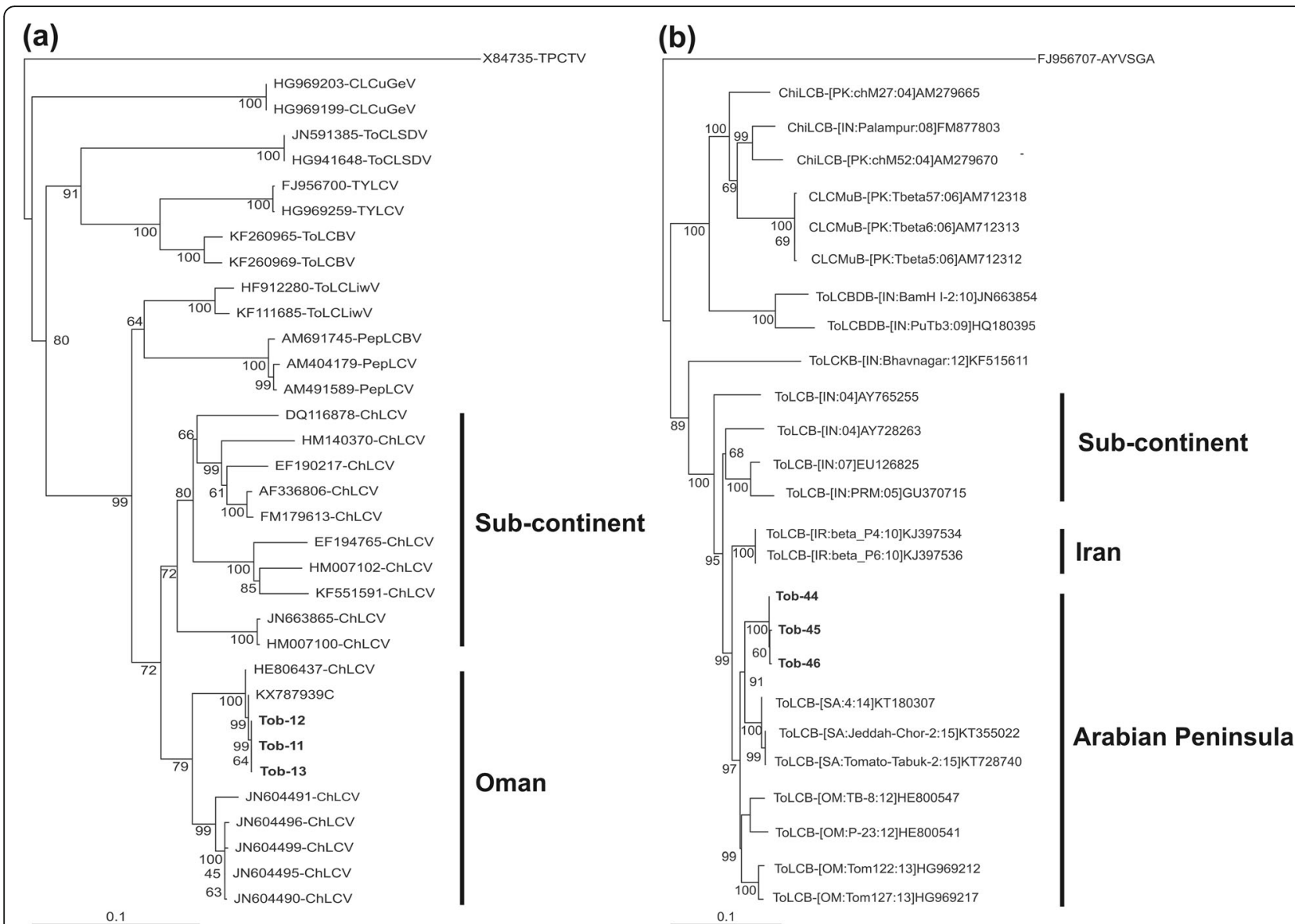

Fig. 2 Phylogenetic dendrograms based upon alignments of the complete nucleotide sequences of the ChiLCV (a) or ToLCB (b) clones obtained from tobacco in Oman with selected begomovirus and betasatellite sequences obtained from the databases. Vertical branches are arbitrary, horizontal branches are proportional to calculated mutation distance. Values at nodes indicate percentage boot strap values (1000 replicates). Begomovirus acronyms used are Chilli leaf curl virus (ChLCV), Cotton leaf curl Gezira virus (CLCuGeV), Pepper leaf curl virus (PepLCV), Tomato leaf curl Liwa virus (ToLCLwV), Tomato leaf curl Sudan virus (ToLCSDV) and Tomato yellow leaf curl virus (TYLCV). The betasatellite acronyms used are Chilli leaf curl betasatellite (ChiLCB), Cotton leaf curl Multan betasatellite (CLCuMuB), Tomato leaf curl Bangladesh betasatellite (ToLCBDB), Tomato leaf curl betasatellite (ToLCB) and Tomato leaf curl Karnataka betasatellite (ToLCKB). The trees were arbitrarily rooted on the sequence Tomato pseudo-curly top virus (TPCTV; X84735), for the virus tree, and Ageratum yellow vein Singapore alphasatellite (AYVSGA; FJ956707), for the betasatellite tree, as outgroup. The database accession numbers are indicated in each case. The sequences originating from tobacco are indicated by bold text in each case. The geographical origins of ChiLCV and ToLCB sequences are indicated on the right in each case

Table 2 Infectivity of Chilli leaf curl virus and associated Tomato leaf curl betasatellite by Agrobacterium-mediated inoculation

\begin{tabular}{|c|c|c|c|c|c|c|c|c|c|c|}
\hline \multirow[t]{3}{*}{ Plant } & \multicolumn{5}{|l|}{ ChLCV } & \multicolumn{5}{|c|}{ ChLCV and ToLCB } \\
\hline & \multicolumn{3}{|c|}{ Plants symptomatic/plants inoculated } & \multirow[t]{2}{*}{ Symptoms ${ }^{a}$} & \multirow{2}{*}{$\begin{array}{l}\text { Latent } \\
\text { period }^{b} \\
\text { (dpi) }\end{array}$} & \multicolumn{3}{|c|}{ Plants symptomatic /plants inoculated } & \multirow[t]{2}{*}{ Symptoms $^{\mathrm{a}}$} & \multirow{2}{*}{$\begin{array}{l}\text { Latent } \\
\text { Period } \\
\text { (dpi) }^{b}\end{array}$} \\
\hline & Exp. 1 & Exp. 2 & Exp. 3 & & & Exp. 1 & Exp. 2 & Exp. 3 & & \\
\hline N. benthamiana & $8 / 8$ & $7 / 8$ & $8 / 8$ & sulr, vs & 16 & $8 / 8$ & $8 / 8$ & $8 / 8$ & sdlc, cr & 12 \\
\hline N. glutinosa & $7 / 8$ & $8 / 8$ & $6 / 8$ & $\mathrm{cr}$ & 21 & $8 / 8$ & $7 / 8$ & $8 / 8$ & sdlc, cr & 18 \\
\hline N. tabacum & $5 / 8$ & $4 / 8$ & $3 / 8$ & $\mathrm{mcr}$, & 21 & $6 / 8$ & $4 / 8$ & $5 / 8$ & mdlr, mer & 18 \\
\hline
\end{tabular}

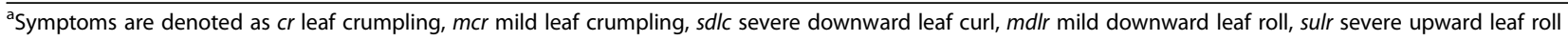
and $v$ s foliar vein swelling

${ }^{\mathrm{b}}$ Time between inoculation and first appearance of symptoms 


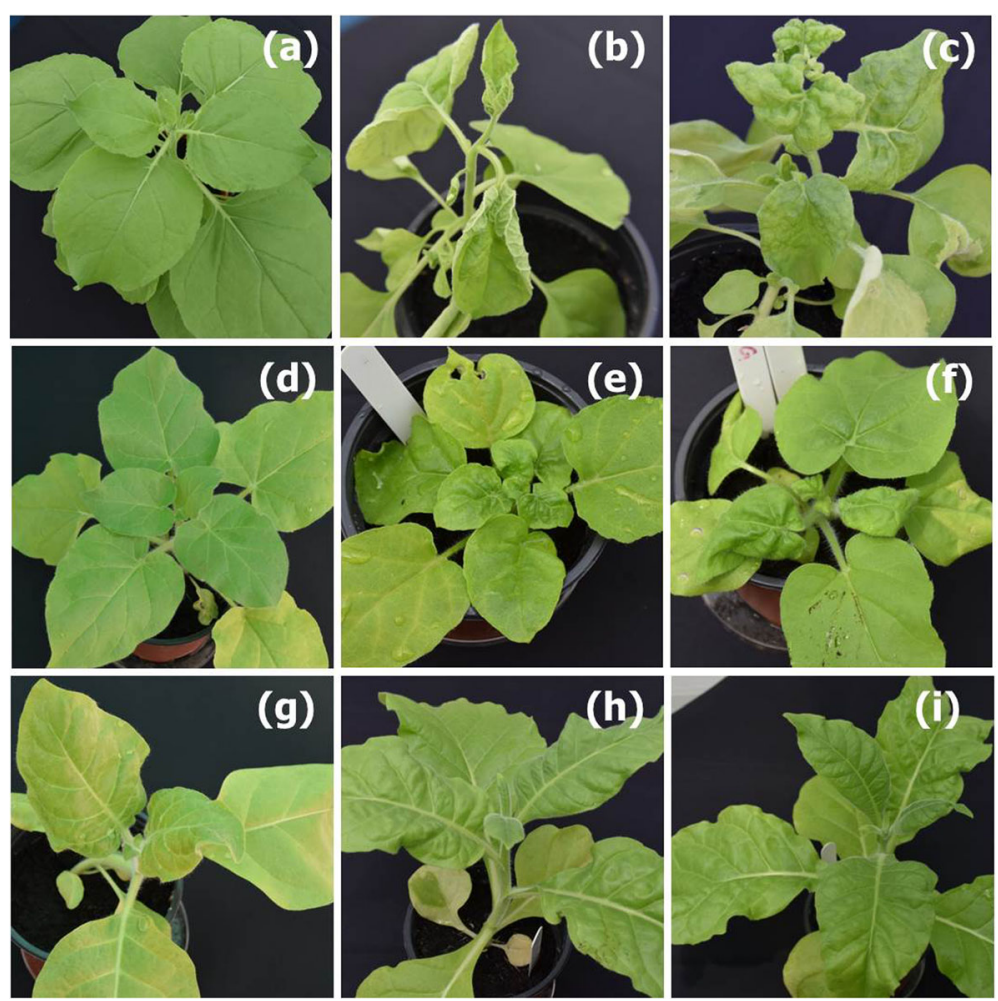

Fig. 3 Symptoms induced in three plant species by Agrobacterium-mediated inoculation with ChiLCV and ToLCB. Shown are Nicotiana benthamiana (a-c), N. glutinosa (d-f) and N. tabacum ( $\mathbf{g}$-i) plants either mock inoculated with an Agrobacterium culture harbouring an empty binary vector $(\mathbf{a}, \mathbf{d}, \mathbf{g})$, inoculated with an Agrobacterium culture harbouring a binary vector construct for the infectivity of ChiLCV (b, e, h), or coinoculated with Agrobacterium cultures harbouring binary vector constructs for the infectivity of ChiLCV and ToLCB (c, f, i). Plants were photographed at 24 days after inoculation

ToLCB resulted in severe downward leaf curling and crumpling young, newly developing leaves at $12 \mathrm{dpi}$.

Inoculation of $N$. glutinosa with only the ChiLCV construct resulted in leaf crumpling which initiated at 21 dpi. As was the case for $N$. benthamiana, co-inoculation of $N$. glutinosa with the construct for ToLCB resulted in symptoms which appeared earlier (18 dpi) and the symptoms showed a pronounced downward leaf curling. Similarly for $N$. tabacum inclusion of ToLCB in the inoculum led to a decrease in latent period (from 21 to 18 dpi) and an increase in symptom severity, with slightly more severe downward leaf curling, although this was less pronounced than for either N. benthamiana or $N$. glutinosa. However, for both singly inoculated plants and co-inoculated plants, the infectivity was significantly less to N. tabacum (50 and 60\%, respectively) than to either of the other Nicotiana species.

The presence of either ChiLCV, or ChiLCV and ToLCB, was confirmed in all symptomatic inoculated plants by diagnostic PCR, whereas neither component was identified in non-inoculated and non-symptomatic inoculated plants. Southern blot analysis of DNA samples extracted from inoculated plants showed the presence of large amounts of viral DNA in both singly and co-inoculated plants and high amounts of betasatellite DNA for co-inoculated plants for $N$. benthamiana and N. glutinosa (Fig. 4). However, for N. tabacum, although there was a large amount of viral DNA detected for the plant inoculated with ChiLCV alone, much less was detected in the plant co-inoculated with ChiLCV and ToLCB. Nevertheless, the amount of viral DNA detected was comparable to the amount of viral DNA detected in field infected tobacco plant, although the amount of betasatellite detected was significantly less. For all inoculated plants, as well as the field collected plant, there was a pronounced smear of small molecular weight material below the viral and betasatellite ssDNA forms.

\section{Discussion}

In Oman tobacco is a minor crop, grown on a small scale and only for local consumption. The results obtained here show that leaf curl symptoms in tobacco in Oman are caused by ChiLCV in association with the betasatellite ToLCB.

Only two betasatellites have been identified in Oman so far identified; ToLCB and Okra leaf curl Oman betasatellite [26]. ToLCB is believed to have its origins on the Indian sub-continent and to have been introduced to 


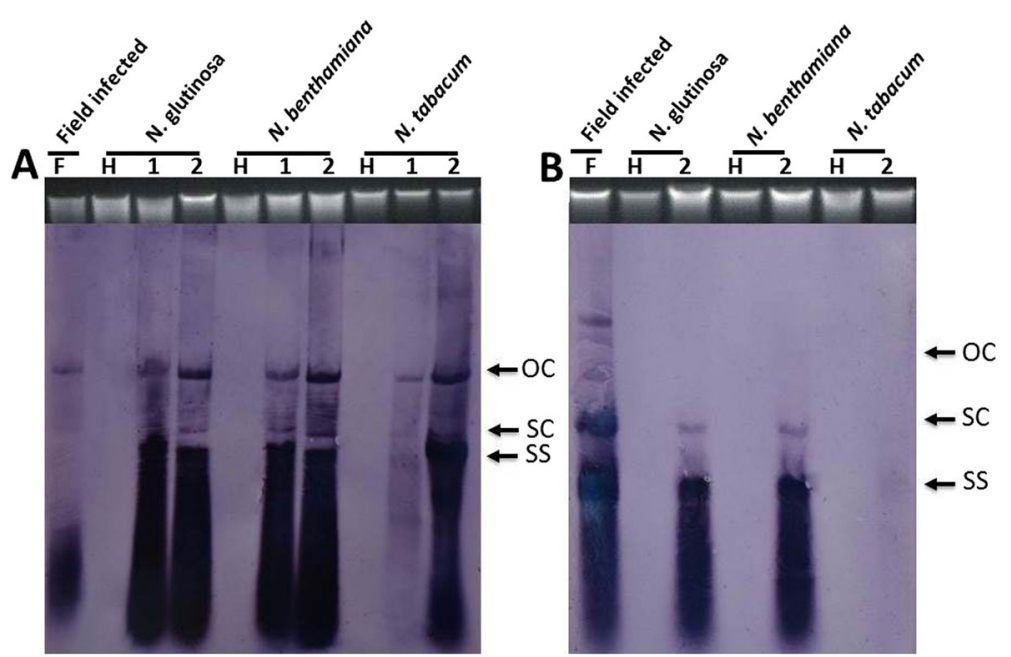

Fig. 4 Southern blot analysis of DNA extracted from agroinoculated N. tabacum plants. Blots were probed for the presence of ChiLCV (a) and ToLCB (b). The samples run on the gels were extracted from Nicotiana glutinosa, N. benthamiana, and N. tabacum plants (as indicated) inoculated with only ChiLCV (lane 1 panel A) or co-inoculated with ChiLCV and ToLCB (lane 2 in panels A and B). In addition DNA extracted from one of the field-infected tobacco plants (F) and from a healthy, non-inoculated tobacco plant (H) was included as controls. In each case approx. $10 \mu \mathrm{g}$ of DNA was loaded. For each blot a photograph of the ethidium bromide-stained genomic DNA band on the gel is shown to confirm equal loading. The positions of viral/betasatellite single-stranded (ss), supercoiled (sc) and open-circular DNA forms are indicated

Oman from there. The results shown here suggest that, rather than being a direct introduction from the subcontinent, ToLCB was instead introduced into Oman indirectly, via Iran. The phylogenetic analysis certainly supports this idea, as well as the subsequent onward spread of this betasatellite across other parts of the Arabian Peninsula [27]. Possibly as a consequence of the low levels of diversity in betasatellites, ToLCB has become associated with a number of begomoviruses and causing disease a number of crops in Oman including, most recently, with the bipartite begomovirus Mungbean yellow mosaic India virus in bean [15]. The association of ChiLCV with ToLCB has also been shown to cause diseases of watermelon, chilli pepper and tomato in Oman $[9,25]$.

In common with ToLCB, ChiLCV has its origins on the sub-continent and is thought to have been introduced to Oman from there $[9,25]$. In contrast to ToLCB, however, the virus has not so far been identified in Iran, so the possible route of introduction is a little less clear.

The symptoms induced by $N$. benthamiana by ChiLCV in the presence and absence very much resemble the symptoms induced in this host by Ageratum yellow vein virus in the presence and absence of its cognate betasatellite, Ageratum yellow vein betasatellite [28]. The change in symptoms in $N$. benthamiana, from an upward leaf roll to a severe downward leaf curl, has been shown to be due to betasatellites encoding a dominant symptom determinant (pathogenicity determinant) and has been shown previously for infection of $N$. benthamiana with ChiLCV and the betasatellite Tomato leaf curl Bangladesh betasatellite (ToLCBDB) and another Oman isolate of ChiLCV with ToLCB [9, 30]. Although Singh et al. [29] showed ToLCBDB to enhance the levels of ChiLCV DNA in N. benthamiana, the results of Khan et al. [9] mirrored the results obtained here; no enhancement of viral DNA levels by ToLCB. This suggests that either the virus isolates differ in their responses to betasatellites or the two betasatellites differ in their interaction with ChiLCV. This will require further investigation in the future.

Although qualitatively the symptoms induced by inoculation of $N$. tabacum with cloned ChiLCV and ToLCB resemble those seen in field infected plants, quantitatively they do not; the symptoms in fieldinfected plants being more severe. There are a number of possible reasons for this. It is possible that the clones obtained from tobacco are not very pathogenic (natural variants). Alternatively the conditions in the glasshouses where the experiments were conducted, required to keep whiteflies away from the experimental plants, may not be ideal for either tobacco or virus propagation. It is interesting to note that, in both experimentally inoculated plants and field collected plants there is a smear of fast migrating, small molecular weight material which hybridizes to the virus and betasatellite probes. This likely represents defective viral/betasatellite DNA replication products which may suggest that species of Nicotiana are not good hosts for ChiLCV and ToLCB. This idea is supported by the relatively low virus DNA levels which are present in N. tabacum. Nevertheless, 
the results show that the leaf curl disease of tobacco in Oman is caused by ChiLCV with ToLCB.

\section{Conclusions}

The study here is the first identification of ChiLCV infecting tobacco, as well as the first identification of ToLCB in tobacco. This virus and betasatellite do not cause disease of tobacco in their regions of geographic origin. This finding is in-line with earlier studies showing that, despite the low diversity of begomoviruses and betasatellites in Oman in comparison to the subcontinent, the extant viruses/betasatellites are able to fill the niches that present themselves. Careful monitoring will be required to assess the threat of local viruses and satellites as agriculture in Oman expands and seeks to introduce new crops and crop varieties.

\section{Supplementary information}

Supplementary information accompanies this paper at https://doi.org/10. 1186/s12985-019-1235-4

Additional file 1: Table S1. Features of Chilli leaf curl virus and associated Tomato leaf curl betasatellite clones isolated from field infected tobacco.

\begin{abstract}
Abbreviations
AYVSGA: Ageratum yellow vein Singapore alphasatellite; BLASTn: Basic Local Alignment Search Tool nucleotide; BYW: Bhendi yellow vein virus; ChiLCB: Chilli leaf curl betasatellite; ChLCV: Chilli leaf curl virus; CLCuGeV: Cotton leaf curl Gezira virus; CLCuMuB: Cotton leaf curl Multan betasatellite; CroYVMB: Croton yellow vein mosaic betasatellite; DNA: Deoxyribonucleic acid; HoLCV: Hollyhock leaf curl virus; nt: nucleotides; oLCBDB: Tomato leaf curl Bangladesh betasatellite; OLCuB: Okra leaf curl betasatellite; ORF: Open reading frame; PaLCuB: Papaya leaf curl betasatellite; PCR: Polymerase chain reaction; PeLCV: Pedilanthus leaf curl virus; PepLCBDV: Pepper leaf curl Bangladesh virus; PepLCV: Pepper leaf curl virus; RCA: Rolling-circle amplification; SDT: Species Demarcation Tool; ToLCB: Tomato leaf curl betasatellite; ToLCJV: Tomato leaf curl Joydebpur virus; ToLCKB: Tomato leaf curl Karnataka betasatellite; ToLCLwV: Tomato leaf curl Liwa virus; ToLCRaB: Tomato leaf curl Ranchi betasatellite; ToLCSDV: Tomato leaf curl Sudan virus: TPCTV: Tomato pseudo-curly top virus; TYLCV: Tomato yellow leaf curl virus
\end{abstract}

\section{Acknowledgments}

The authors are thankful to the farmers and technicians who assisted in field surveys and sample collection.

\section{Authors' contributions}

MSS conceived the study and supervised the work. MSS, MS and AR performed the experimental work. MSS, MS AMA and RWB analysed the data. MSS and MS prepared the first draft of the manuscript which was edited by RWB and AMA. The final manuscript was read and approved by all authors.

\section{Funding}

This research was supported by Sultan Qaboos University through the strategic grants SR/AGR/CROP/16/01 and IG/AGR/CROP/17/02.

\section{Availability of data and materials}

The full-length sequences determined in this study were submitted to GenBank with the accession numbers MK468694 - MK468699. The datasets and materials produced for the study are available from the corresponding author on reasonable request.
Ethics approval and consent to participate

Not applicable.

\section{Consent for publication}

Not applicable.

\section{Competing interests}

The authors declare that they have no competing interests.

\section{Author details}

${ }^{1}$ Department of Crop Sciences, College of Agricultural and Marine Sciences, Sultan Qaboos University, Al-Khod, 123 Muscat, Oman. ${ }^{2}$ Agricultural Biotechnology Division, National Institute for Biotechnology and Genetic Engineering, Faisalabad, Pakistan.

Received: 21 July 2019 Accepted: 3 October 2019

Published online: 09 November 2019

\section{References}

1. Zerbini FM, Briddon RW, Idris A, Martin DP, Moriones E, Navas-Castillo J, Rivera-Bustamante R, Varsani A, Consortium IR. ICTV virus taxonomy profile: Geminiviridae. J Gen Virol. 2017:98:131-3.

2. Hanley-Bowdoin L, Bejarano ER, Robertson D, Mansoor S. Geminiviruses: masters at redirecting and reprogramming plant processes. Nat Rev Microbiol. 2013;11:777-88.

3. Briddon RW, Stanley J. Sub-viral agents associated with plant singlestranded DNA viruses. Virology. 2006;344:198-210.

4. Zhou X. Advances in understanding begomovirus satellites. Annu Rev Phytopathol. 2013;51:357-81.

5. Briddon RW, Bull SE, Amin I, Idris AM, Mansoor S, Bedford ID, Dhawan P Rishi N, Siwatch SS, Abdel-Salam AM, et al. Diversity of DNA $\beta$ : a satellite molecule associated with some monopartite begomoviruses. Virology. 2003; 312:106-21.

6. Khan AJ, Mansoor M, Briddon RW. Oman: a case for a sink of begomoviruses of geographically diverse origins. Trends Plant Sci. 2014;19:67-70.

7. Khan AJ, Akhtar S, Singh AK, Briddon RW. A distinct strain of Tomato leaf curl Sudan virus causes tomato leaf curl disease in Oman. Plant Dis. 2013;97: 1396-402.

8. Khan AJ, Akhtar S, Al-Matrushi AM, Fauquet CM, Briddon RW. Introduction of east African cassava mosaic Zanzibar virus to Oman harks back to "Zanzibar, the capital of Oman". Virus Genes. 2013;46:195-8.

9. Khan AJ, Akhtar S, Al-Zaidi AM, Singh AK, Briddon RW. Genetic diversity and distribution of a distinct strain of Chili leaf curl virus and associated betasatellite infecting tomato and pepper in Oman. Virus Res. 2013:177:87-97.

10. Khan A, Idris A, Al-Saady N, Al-Mahruki M, Al-Subhi A, Brown J. A divergent isolate of Tomato yellow leaf curl virus from Oman with an associated DNAB satellite: an evolutionary link between Asian and the middle eastern virussatellite complexes. Virus Genes. 2008:36:169-76.

11. Khan AJ, Akhtar S, Briddon RW, Ammara U, Al-Matrushi AM, Mansoor S. Complete nucleotide sequence of Watermelon chlorotic stunt virus originating from Oman. Viruses. 2012;4:1169-81.

12. Porebski S, Bailey LG, Baum BR. Modification of a CTAB DNA extraction protocol for plants containing high polysaccharide and polyphenol components. Plant Mol Biol Rep. 1997;15:8-15.

13. Shahid MS, Pudashini BJ, Khatri-Chhetri GB, Briddon RW, Natsuaki KT. Molecular characterization of a distinct monopartite begomovirus associated with betasatellites and alphasatellites infecting Pisum sativum in Nepal. Virus Genes. 2017;53:300-6.

14. Bull SE, Briddon RW, Markham PG. Universal primers for the PCR-mediated amplification of DNA 1: a satellite-like molecule associated with begomovirus-DNA $\beta$ complexes. Mol Biotechnol. 2003:23:83-6.

15. Shahid MS, Briddon RW, Al-Sadi AM. Identification of Mungbean yellow mosaic Indian virus associated with tomato leaf curl betasatellite infecting Phaseolus vulgaris in Oman. J Phytopathol. 2017;165:204-11.

16. Altschul SF, Gish W, Miller W, Myers EW, Lipman DJ. Basic local alignment search tool. J Mol Biol. 1990;215:403-10.

17. Muhire BM, Varsani A, Martin DP. SDT: a virus classification tool based on pairwise sequence alignment and identity calculation. PLoS One. 2014;9: e108277. 
18. Tamura K, Stecher G, Peterson D, Filipski A, Kumar S. MEGA6: molecular evolutionary genetics analysis version 6.0. Mol Biol Evol. 2013;30:2725-9.

19. Page RDM. TREEVIEW: an application to display phylogenetic trees on personal computers. Comput Appl Biosci. 1996:12:357-8.

20. Hellens RP, Edwards EA, Leyland NR, Bean S, Mullineaux PM. pGreen: a versatile and flexible binary Ti vector for Agrobacterium-mediated plant transformation. Plant Mol Biol. 2000;42:819-32.

21. Hussain M, Mansoor S, Iram S, Zafar Y, Briddon RW. The hypersensitive response to tomato leaf curl New Delhi virus nuclear shuttle protein is inhibited by transcriptional activator protein. Mol Plant-Microbe Interact. 2007:20:1581-8.

22. Shahid MS, Aboughanem-Sabanadzovic N, Sabanadzovic S, Tzanetakis IE. Genomic characterization and population structure of a badnavirus infecting blackberry. Plant Dis. 2017;101:110-5.

23. Laney AG, Hassan M, Tzanetakis IE. An integrated badnavirus is prevalent in fig germplasm. Phytopathology. 2012;102:1182-9.

24. Brown JK, Zerbini FM, Navas-Castillo J, Moriones E, Ramos-Sobrinho R, Silva JF, Fiallo-Olivé E, Briddon RW, Hernández-Zepeda C, Idris A, et al. Revision of Begomovirus taxonomy based on pairwise sequence comparisons. Arch Virol. 2015;160:1593-619.

25. Shahid MS, Al-Sadi AM, Briddon RW. First report of Chilli leaf curl virus and tomato leaf curl betasatellite infecting watermelon (Citrullus lanatus) in Oman. Plant Dis. 2017;101:1063.

26. Akhtar S, Khan AJ, Singh AS, Briddon RW. Identification of a disease complex involving a novel monopartite begomovirus with beta- and alphasatellites associated with okra leaf curl disease in Oman. Arch Virol. 2014;159:1199-205.

27. Sohrab SS, Yasir M, El-Kafrawy SA, Abbas AT, Mousa MAA, Bakhashwain AA. Association of tomato leaf curl Sudan virus with leaf curl disease of tomato in Jeddah, Saudi Arabia. Virus Dis. 2016;27:145-53.

28. Saunders K, Norman A, Gucciardo S, Stanley J. The DNA $\beta$ satellite component associated with ageratum yellow vein disease encodes an essential pathogenicity protein ( $\beta C 1$ ). Virology. 2004;324:37-47.

29. Singh AK, Kushwaha N, Chakraborty S. Synergistic interaction among begomoviruses leads to the suppression of host defense-related gene expression and breakdown of resistance in chilli. Appl Microbiol Biotechnol. 2016:100:4035-49.

30. Shahid MS, Raza A, Shafiq M, Al-Sadi MA, Briddon RW. Infection of Urtica incisa with Chili leaf curl virus and tomato leaf curl betasatellite in Oman. J Plant Pathol. 2019;101:395

\section{Publisher's Note}

Springer Nature remains neutral with regard to jurisdictional claims in published maps and institutional affiliations.

Ready to submit your research? Choose BMC and benefit from:

- fast, convenient online submission

- thorough peer review by experienced researchers in your field

- rapid publication on acceptance

- support for research data, including large and complex data types

- gold Open Access which fosters wider collaboration and increased citations

- maximum visibility for your research: over $100 \mathrm{M}$ website views per year

At $\mathrm{BMC}$, research is always in progress.

Learn more biomedcentral.com/submissions 